control ration; (b) a 50 per cent control ration plus 50 per cent crushed linseed meal-experimental ration; (c) an experimental ration plus supplementary aqueous potassium iodide; $(d)$ a control ration plus aqueous potassium cyanide ; (e) a control ration plus aqueous potassium thiocyanate. Random samples were taken from each of these groups and $1 \mu \mathrm{c}$. radioactive iodine injected intraperitoneally into each. By means of a specially arranged Geiger counter, the radioiodine uptake curves were obtained for each thyroid. Comparison between the curves obtained confirmed the prophylactic effect of supplementary iodide, and identified the goitrogenic principle as thiocyanate, produced as a detoxication product of cyanide.

Linseed has been shown to contain the cyanogenetic glucoside, linamarin. This, Coop and Blakley ${ }^{1}$ demonstrated, was hydrolysed in the rumen of a sheep and the cyanide produced was detoxicated by the liver in the form of thiocyanate. That this is so was confirmed by the similarity between the radioiodine uptake curves exhibited by pregnant ewes fed a ration of linseed meal, oats and lucerne hay, mice fed an experimental ration containing 50 per cent crushed linseed meal, and finally mice fed a control diet to which had been added aqueous potassium thiocyanate.

A start has also been made upon the investigation of the goitrogenic properties of white clovers (Trifolium repens L.), since these contain the cyanogenetic glucoside, lotaustralin, in amounts dependent upon the particular strain of elover ${ }^{2}$. Both radioiodine uptake curves and chemical analyses have given indications of a' goitrogenic effect. The suggestion is put forward that incipient goitre, arising from low soil iodine contents and excessive use of lush growths of white clover, may bring about a retardation in the rate of fattening of lambs reared in such an environment.

A full account of this work will be published elsewhere in due course.

I wish to acknowledge the help and advice of Prof. I. E. Coop and the staff of Canterbury Agricultural College, and the assistance of the New Zealand Department of Scientific and Industrial Research in the form of a National Research Scholarship.

Canterbury Agricultural College,

$$
\text { A. D. CARE }
$$

Lincoln, N.Z. Sept. 25.

${ }^{1}$ Coop, I. E., and Blakley, R. L., N.Z.J. Sci, and Tech., 31 A, 1 (1949). 'Doak, B. W., N.Z. J. Sci. and Tech., 14, 359 (1933)

\section{Carnitine (Vitamin BT) as a Nutritional Requirement for the Confused Flour Beetle}

THIS is a preliminary report on experiments now in progress to determine the nutritive requirements of the confused flour beetle, Tribolium confusum Duval.

It has previously been shown ${ }^{1}$ that this beetle, which normally feeds on flour and other dried stored products, will grow satisfactorily on a synthetic diet consisting of 50 parts casein, 50 parts glucose, 1 part cholesterol, 1 part McCollum's salt mixture, and the following vitamins of the B-complex ; thiamin, riboflavin, nicotinic acid, pyridoxine, pantothenic acid, choline chloride, folic acid, biotin, and possibly inositol. In an attempt to determine more exactly its specific nutritive requirements, it was noted that, although larval growth was adequately maintained on the above diet, and pupation occurred, the adults which emerged from the pupæ usually died shortly after. Often these adults died well before the cuticle had become tanned and hardened.

Experiments were initiated to determine what factor was missing in the diet which could account for such an abnormality. It was found that this factor could be supplied by the addition of either whole yeast, or its water-soluble fraction, to the basic diet. It was further noted that these deficiency symptoms appeared to be similar to those already described for the yellow mealworm, Tenebrio molitor L. ${ }^{2}$, and for the small-eyed flour beetle, Palorus ratzeburgi $\mathrm{W}_{\text {iss. }}{ }^{3}$, in which the larvæ raised on diets deficient in carnitine died shortly after a moult. Since carnitine is contained in the water-soluble fraction of yeast, it was added in various increments to the diet of Tribolium confusum Duv., in order to determine what effect it might have on the adults which emerged.

As may be seen in the accompanying table, larvæ reared on the synthetic diet, either in the presence or absence of carnitine, were similar in respect to survival, degree of weight attained, and number of days which it took them to pupate. The pupæ likewise appeared to be similar. However, the great majority of larvæ reared on the synthetic diet without carnitine yielded adults which displayed the type of abnormality already described; whereas, when carnitine was added to the diet, all the adults which emerged were normal.

Developmant of Tribolium confusum IN THE PRESENCE OR Forty larvæ were used in each experiment, at $30^{\circ} \mathrm{C}$. and 60 per cent relative humidity
rexp larvæ were used in each experiment,

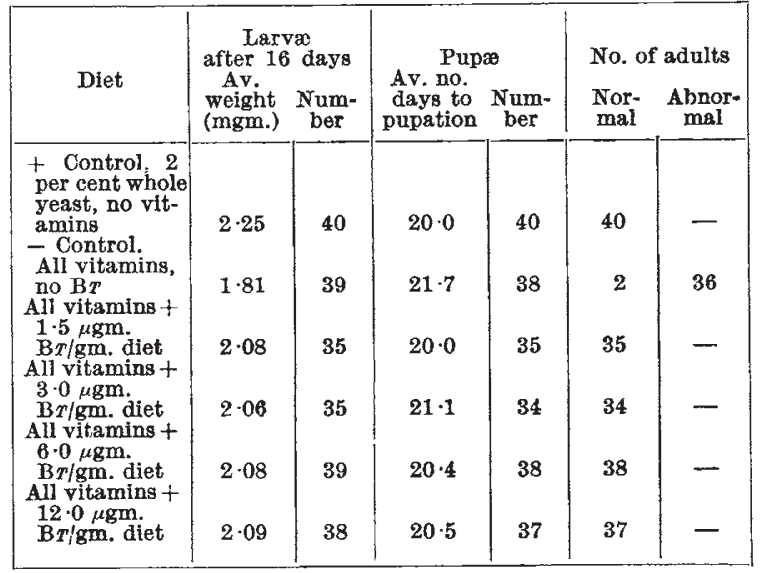

Carnitine, therefore, is a dietary essential for Tribolium confusum Duv.

Added in proof (January 4, 1954). In a note by G. Fröbrich and K. Offhaus (Naturwissenschaften, 39, 575 (1952) ), the presence of a 'Tribolium-ImagoFaktor' (TIF) was postulated. TIF was assumed to be a peptide. From the data presented above it is virtually certain that TIF is carnitine.

\section{Ellery W. Fren Ch} G. Fraenket

Department of Entomology,

University of Illinois,

Urbana, III.

Sept. 29.

1 Fraenkel, $G_{.,}$and Blewett, M, Biochem. $J ., 37,686$ (1943) ; 41, 469 (1947).

${ }^{2}$ Fraenkel, G., et al., Nature, 161, 981 (1948). Fraenkel, G., Biol. Bull., 27 (in the press).

- Cooper, M., and Fraenkel, G., Physiol. Zool., 25, 20 (1952). 